IRSH 64 (2019), pp. 73-109 doi:10.1017/S0020859019000063

(C) 2019 Internationaal Instituut voor Sociale Geschiedenis. This is an Open Access article, distributed under the terms of the Creative Commons Attribution licence (http:// creativecommons.org/licenses/by/4.o/), which permits unrestricted re-use, distribution, and reproduction in any medium, provided the original work is properly cited.

\title{
VIRTUAL SPECIAL ISSUE
}

\section{Labour History and the Case against Colonialism}

Vijay Prashad, "Marks of Capital: Colonialism and the Sweepers of Delhi”, 40:I (I995), pP. I-30

Ibrahim Abdullah, "'Liberty or Death': Working Class Agitation and the Labour Question in Colonial Freetown, I938-1939”, 40:2 (I995), pp. I9522 I

Gyan Prakash, "Colonialism, Capitalism and the Discourse of Freedom”, 4I: $\mathrm{SI}_{4}$ "Peripheral" Labour? Studies in the History of Partial Proletarianization (I996), pp. I I-25

Samita Sen, "Gendered Exclusion: Domesticity and Dependence in Bengal”, 42:SIs The Rise and Decline of the Male Breadwinner Family? (I997), pp. $65-86$

Ravi Ahuja, "The Origins of Colonial Labour Policy in Late EighteenthCentury Madras”, 44:2 (I999), pp. I59-I95

Ian J. Kerr, "On the Move: Circulating Labor in Pre-Colonial, Colonial, and Post-Colonial India”, 5 I:SIr 4 Coolies, Capital, and Colonialism: Studies in Indian Labour History (2006), pp. 85-109

Julia Martínez, “When Wages Were Clothes: Dressing down Aboriginal Workers in Australia's Northern Territory”, 52:2 (2007), pp. 271-286

Stefan Halikowski Smith, "The Mid-Atlantic Islands: A Theatre of Early Modern Ecocide", 55:SII8 Globalization, Environmental Change, and Social History (2010), pp. $5 \mathrm{I}-78$

Alexander Keese, "Slow Abolition within the Colonial Mind: British and French Debates about 'Vagrancy', 'African laziness', and Forced Labour in West Central and South Central Africa, I945-i 965”, 59:3 (2014), pp. 377-407

Ian Phimister and Alfred Tembo, “A Zambian Town in Colonial Zimbabwe: The I964 'Wangi Kolia' Strike”, 60:SI23 Migration and Ethnicity in Coalfield History: Global Perspectives (2015), pp. 4I-62

Elise van Nederveen Meerkerk, "Grammar of Difference? The Dutch Colonial State, Labour Policies, and Social Norms on Work and Gender, 
c.I 800-1940", 61:SI24 Conquerors, Employers and Arbiters: States and Shifts in Labour Relations, I500-2000 (20I6), pp. I37-164

Andrea Rapini, "Can Peasants Make a Revolution? Colonialism, Labour, and Power Relations in Pierre Bourdieu’s Algerian Inquiries”, 6r:3 (2016), pp. $389-42$ I

$$
\text { PEPIJN BRANDON* }
$$

International Institute of Social History and Vrije Universiteit (VU) Amsterdam, Cruquiusweg 31, IOI9 AT Amsterdam, The Netherlands

E-mail: pepijn.brandon@iisg.nl

\title{
A DITYA SARKAR \\ Department of History, University of Warwick Humanities Building, University Road, Coventry, $\mathrm{CV}_{4}{ }_{7} A L$, United Kingdom
}

E-mail: Aditya.Sarkar@warwick.ac.uk

\begin{abstract}
The controversy around Bruce Gilley's article "The Case for Colonialism" has drawn global attention to a stream of revisionist claims and visions on the history of colonialism that has emerged in academia and in the media in recent years. Authors such as Nigel Biggar in the UK, Niall Ferguson in the USA, and Pieter Emmer in the Netherlands, have all published similarly revisionist claims about colonialism, arguing that postcolonial guilt and political correctness blind the majority of their colleagues to the positive side of the colonial project. Their argument chimes with wider societal trends, transforming the revisionist defenders of empire into heroes of a reinvigorated nationalist right within and beyond academia. The public influence attained by these approaches to colonialism requires historians to expose the deep methodological flaws, misreading of historical facts, and misrepresentations of prior scholarship that characterize the writings of this emerging revisionist trend. It is for this reason that the Editorial Committee of the International Review of Social History (IRSH) has decided to devote its first ever Virtual Special Issue to labour history's case against colonialism. This article, also an introduction to the Virtual Special Issue, sifts through the logical implications of the claims made by Gilley and like-minded scholars, providing both a contextualization and a rebuttal of their arguments. After assessing the long absence of colonial labour relations from the field of interest of labour historians and the pages of the IRSH itself, this article shows the centrality of a critique of colonialism to labour history's global turn in the I990s. Using a selection of articles on colonial labour history from the IRSH's own archive, the article not only
\end{abstract}

\footnotetext{
* Pepijn Brandon contributed to this article while working on a project funded by NWO under grant number 275-53-015.
} 
reconstructs "labour history's case against colonialism", but also shows why labour history's critical insights into the nature of colonialism should be deepened and extended, not discarded.

In September 20I7, Third World Quarterly published an article by Bruce Gilley, a scholar in Political Science at the University of Portland, entitled "The Case for Colonialism". The article argued that the benefits of European colonialism far exceeded its costs, identified "good governance" as the deepest legacy of the colonizing mission, and advocated the resurrection of colonialism "without the usual cries of oppression, occupation, and exploitation". 'Gilley's arguments provoked an immediate and extensive response. Nearly half of the editorial board of Third World Quarterly resigned in protest against the decision to publish an open defence of colonialism in a journal long known for its anti-colonial credentials. ${ }^{2}$ A petition signed by over 10,000 academics attacked the article for shoddy scholarship and uncontrolled bias and demanded its retraction. ${ }^{3}$ A lively debate commenced in corners of academic and public opinion, and produced several illuminating ripostes and rebuttals. ${ }^{4}$ The article was finally withdrawn: Gilley claimed this was a result of sustained threats and intimidation from within and beyond the academic community.'

Parallel to these events, another controversy broke out over the historical meaning of colonialism towards the end of 2017 . A research programme run

I. Bruce Gilley, “The Case for Colonialism”, Third World Quarterly, (September 2017). Since the article was subsequently withdrawn, it does not have an issue number or page numbers. However, the text can still easily be found online, for example here: http://www.web.pdx.edu/ qilleyb/2_The\% 20case\% 20for\% 20colonialism_at2Oct2017.pdf: last accessed I9 December 2018, where the pages are numbered I-I7. Citation on page II.

2. Colleen Flaherty, "Resignations at Third World Quarterly", 20 September 2017, available at: https://www.insidehighered.com/news/2017/09/20/much-third-world-quarterlys-editorialboard-resigns-saying-controversial-article: last accessed 3 December 20 I 8.

3. Adam Lusher, "Professor's 'Bring Back Colonialism' Call Sparks Fury and Academic Freedom Debate", The Independent, I 2 October 2017.

4. See, in particular, Nathan J. Robinson, "A Quick Reminder of Why Colonialism Was Bad", Current Affairs: A Magazine of Politics And Culture, I4 September 2017, available at: https:// www.currentaffairs.org/2017/09/a-quick-reminder-of-why-colonialism-was-bad; last accessed I9 December 20I8; Naeem Inayatullah, "The Eternal Return of Benign Colonialism", 7 October 2017, available at: https://thedisorderofthings.com; last accessed I9 December 2018; Swati Parashar, "Beyond 'The Case For Colonialism': Rethinking Academic Practices and Dissent”, 8 October 2017, available at: https://thedisorderofthings.com; last accessed I9 December 2018; Vijay Prashad, "Third World Quarterly Row: Why Some Western Intellectuals are Trying to Debrutalise Colonialism”, 21 September 2017, available at: https:// scroll.in; last accessed ig December 2018.

5. Bruce Gilley, "How the Hate Mob Tried to Silence Me", Standpoint Magazine, December $2017 /$ January 2018. 
by Nigel Biggar, a theologian at Oxford University, named "Ethics and Empire", came in for sustained criticism by scholars in many British universities for seeking to resuscitate old justifications of imperial rule and conduct. ${ }^{6}$ Along with John Darwin (whose involvement was limited to the early stages of the project), Biggar developed a research agenda that received generous financial backing from Oxford - this was a key point in subsequent criticisms. ${ }^{7}$ Couched as an even-handed examination of the "ethics of empire" that would draw historians, philosophers, and theologians into conversation, the framing of the programme implicitly recast empire itself as an ethical project. $^{8}$ Biggar was no stranger to controversy: in 2016 , he had engaged in a debate organized by the Oxford Union on the Rhodes Must Fall campaign, a student movement calling for the removal of the statue of Cecil Rhodes outside Oriel College, following in the footsteps of the previous and successful campaign by South African students at the Witwatersrand University in Cape Town. ${ }^{9}$ During the Oxford Union debate, and on other occasions, Biggar insisted that Rhodes could not credibly be described as a racist, that he did Africans more good than harm, and that celebration of his legacy was apt and just. ${ }^{10}$

As had been the case with Gilley, Biggar's defenders were quick to claim persecution by a dictatorial establishment of left-leaning academics unwilling to listen to dissenting thought. ${ }^{\text {II }}$ This charge carries a particular irony in Britain, where academics critical of empire - notably Priyamvada Gopal at Cambridge University - have been subjected to ranting attacks in the tabloid press in the recent past. ${ }^{\mathrm{I}}$ Nevertheless, familiar charges about the fabled

6. See, for instance, Richard Adams, "Oxford University Accused of Backing Apologists of British Colonialism”, The Guardian, 22 December 2017.

7. For Biggar's own views on colonialism, see his defence of Bruce Gilley in "Don't Feel Guilty about Our Colonial History", The Times, 30 November 2017.

8. McDonald Centre, "Ethics and Empire", available at: http://www.mcdonaldcentre.org.uk/ ethics-and-empire; last accessed I9 December 2018. For an account of the immediate criticism of the project, see Matthew Reisz, "Oxford Project's 'Balance-Sheet View' of Empire Criticised”, Times Higher Education, 22 December 2017, available at: https://timeshighereducation.com; last accessed i9 December 2018.

9. The full debate can be viewed on Oxford Union's YouTube page, available at: https://m. youtube.com/watch?=uPsQF9rbZFA; last accessed i9 December 2018.

I0. For a summary of Biggar's views on Rhodes, see Nigel Biggar, "Message to Students: Rhodes Was No Racist", The Times, 22 December 201 5 . For important critiques, see Jonathan Saha, "Safe Spaces for Colonial Apologists", 8 January 20I 8, available at: http://criticallegalthinking.com; last accessed i9 December 2018; Kenan Malik, "The Great British Empire Debate", The New York Review of Books, 26 January 2018, available at: https://www.nybooks.com/daily/2018/or/26/ the-great-british-empire-debate/; last accessed I 3 December 2018.

I I. See, for instance, Sumantra Maitra, "If I Want to Hold Seminars on the Topic of Empire, I Will Do So Privately': An Interview with Nigel Biggar”, Quillette, 7 June 2018.

I 2. For an account of attack by the British tabloid press on Priyamvada Gopal, see Noella Chye, "Priya Gopal: 'Those in Power are Responding to Threats by Playing Victim'”, Varsity, 27 April 20I 8, available at: https://www.varsity.co.uk/news/i5357; last accessed i9 December 2018. 
intolerance and bigotry of politically correct intellectuals have continued to circulate and gather force. Gilley, Biggar, and like-minded scholars have become heroes for right-wing supporters of the legacy of empire, as well as in diffuse, right-leaning corners of Western humanities, for their courage in telling the "truth" about the colonial past in the face of a hostile progressive orthodoxy that swamps "genuine thinking". From the Right, academic progressivism is seen as a sinister conspiracy against free speech, based on a dogmatic belief in the uniquely evil character of colonialism. The alleged dogma is explained briefly - and with more than a little conceptual confusion - by Sumantra Maitra:

This idea that colonialism was something uniquely evil is a post-colonial Marxist contribution to history, which became popular around the I970s. Marxist academics started writing theory laced non-empirical tomes on it, and an entire discipline of post-colonialism went on to dominate Western academe. ${ }^{\text {I3 }}$

The row provoked by Gilley's article has drawn global attention to the re-emergence of defences of colonialism within the historical profession. However, the debate is certainly not new, nor is it confined to Anglophone academia. ${ }^{14}$ In 2005 , the French scholarly world was shaken by the debates provoked by a law introduced in Parliament that demanded that secondary education should pay particular attention to "the positive role played by French presence overseas, in particular in Northern Africa". ${ }^{\text {is }}$ The clause, which was eventually withdrawn following widespread protest within academic and educational circles, drew on long-present strands within French society as well as the historical profession that want to recast French colonialism as a "good colonialism", reflective of French secular and progressive national values. ${ }^{16}$ More recently, in the Netherlands, the historian of Dutch involvement in the slave trade Pieter Emmer presented the case for colonialism in terms that are remarkably similar, both in content and in style, to Gilley's. Claiming the existence of a collective form of anti-colonial amnesia, he argued that historians and the wider public have forgotten that colonialism:

has put an end to raids and plundering, has dramatically lengthened the life expectancy of colonial subjects, built roads, railroads, telegraph and telephone lines, a plumbing and tap water system, and has reconstituted government and

I3. Sumantra Maitra, "The Jack Tars of the Royal Navy and the Abolition of Slavery", The Salisbury Review: Quarterly Magazine of Conservative Thought, 5 January 2018.

I4. Within Anglophone academia, the trailblazer was Niall Ferguson, Empire: How Britain Made the Modern World (London, 2003).

I5. Claude Liauzu, "Les historiens saisis par les guerres de mémoires coloniales", Revue d'Histoire Moderne E Contemporaine 52:4 (2005), pp. 99-109, citation from Article 4 of the law of 23 February 2005, p. 99.

i6. Sophie Dulucq et al., "L'écriture de l'histoire de la colonisation en France depuis i960", Afrique E Histoire 6 (2006), pp. $235^{-276 .}$ 
the courts on a modern footing. For Asia and Africa, colonialism was the entry ticket into modern civilization. ${ }^{17}$

There is a legitimate concern that trying to refute such avowed nostalgia for the colonial past in fact graces it with a scholarly weight that it does not and should not possess. However, the public influence attained internationally by revisionist approaches to colonialism, as well as the way in which pseudo-scientific notions introduced by writers such as Gilley have begun to filter into more mainstream scholarship, require academic historians to expose the deep methodological flaws, misreading of historical facts, and misrepresentations of prior scholarship that characterize their writing. It is for this reason that the Editorial Committee of the International Review of Social History (IRSH) has decided to devote its first ever Virtual Special Issue to labour history's case against colonialism. The Special Issue consists of a selection of articles published in the IRSH in the previous decades. As even a cursory reading of these articles will make clear, the scholars who uphold empire and casually dismiss anti-colonial viewpoints as bigoted have evidently never engaged seriously with the traditions of thought they disparage. Much of the case for colonialism rests upon tendentious claims about the shoddiness and bias of most, if not all anti-colonial critique. By excavating one important corner of this tradition - research concerned with labour under colonial regimes - this Virtual Special Issue demonstrates the hollowness of such accusations. All these articles, in the editors' view, exemplify the richness and sophistication of critical anti-colonial scholarship, and also demonstrate the role labour history can play in rebutting the claims made by empire revivalists like Gilley.

This article will proceed in two stages: The first part will offer a careful discussion of the historical revisionism advocated by Gilley and others. It will sift through the logical implications of the claims made by empire revivalists, and construct both a contextualization and a rebuttal of their arguments. In doing so, it will mainly concentrate on the recent literature on the British Empire, but, where possible, will show parallels to the debates that have emerged in other former colonizing countries. The second part will focus on the specific contribution that global labour history can make to this controversy. At one level, labour history's relevance for this debate ought to be obvious. One of the driving forces of the colonial project at large was the extraction of natural resources and the cheap supply of precious commodities through the labour of the colonized. Arguably, few aspects of colonial governance were so systematically characterized by open violence as the organization and control of labour.

17. P.C. Emmer, Het zwart-wit denken voorbij. Een bijdrage aan de discussie over kolonialisme, slavernij en migratie (Amsterdam, 2018), p. 32. 
It is a telling sign of their lack of intellectual rigour that most empire revisionists, when talking about the institutional legacies of colonial rule, so effortlessly bypass the long legacies of the institutions built by the colonial powers for the acquisition and use of forced labour. However, labour history's engagement with colonialism also challenges the approach of the revisionists on another level. Far from the easy, near-hegemonic embracing of anti-colonial political correctness conjured up by Gilley and others, even within such a traditionally progressive or even left-wing sub-section of Western academia as labour history, the acknowledgement of the very existence of the colonial world as a legitimate subject of investigation long remained slow and hesitant. The introduction will show this by tracing the IRSH's own turn, as late as the I990s, to a more global perspective encompassing the formerly colonized world. It will then outline the major insights into the experience of labour in the colonial era, which can be gleaned from the republished articles, and argue why these insights should be deepened and extended, rather than dismissed in favour of a celebration of the colonial past.

\section{IS THERE A CASE FOR COLONIALISM? \\ THE LOGIC OF EMPIRE REVIVALISM}

Is there actually a case for colonialism that can be identified and confronted as such, which we can find in the writings of Gilley, Biggar, and some of their contemporaries? At first glance, their claims might seem easy to dismiss. It is manifestly true that the scholarship in these empire apologias is frequently shoddy and substandard and ignores a great deal of countervailing evidence. It also engages in nebulous, declamatory pronouncements. Gilley, for instance, through selective quotation, claims that Africans and Asians never had any sense of human dignity prior to the advent of colonialism. ${ }^{18}$ Beyond such embarrassing instances, however, there is a certain consistency to the arguments made by scholars who seek to defend the memory of imperial rule. The details and emphases vary, but common structuring themes emerge upon a perusal of this literature. False as the premises and arguments are, their internal consistency makes them a potentially powerful reaction against the advances of critical scholarship. Given the often casual and unscrupulous argumentation deployed by defenders of empire, we run the risk of constructing their case for them, giving it a logical cogency that it does not inherently possess. But this is a risk that must be taken, since the elements of a historical recuperation of imperial legacies clearly exist.

The different points in the case made so emphatically by Gilley correspond with and speak to long-running currents of empire justification in other

I 8. Gilley, “The Case”, pp. 3-4. 
work, as well as in substantial pockets of public opinion. To respond adequately to these diffuse elements of a justificatory discourse, we must contextualize them in relation to one another, and in logical sequence. It is necessary to identify and confront the pro-empire claims that recur most frequently and that provide the case for colonialism with its structuring principles, in order to expose their flaws. It may be useful here to briefly itemize these claims, as far as possible, on their own terms:

I. Colonialism, it is claimed, acted as a progressive force in modern history. It brought, in Gilley's words, "the universalism of the liberal peace and with it a shared standard of what a well-governed country looks like". ${ }^{19}$ It reduced child mortality, improved the means of communication, and gave the colonized Western education and Christian values. ${ }^{20}$ Simply put, colonialism undertook a valid civilizing mission and the world is better off for it.

2. Of course, as even Gilley admits, colonialism "was not an unalloyed good". ${ }^{2}$ The colonial powers did occasionally misbehave and there were atrocities, such as the Amritsar massacre or the extreme forms of corporal punishment meted out in Belgian Congo under Leopold's rule. Here, two somewhat contradictory arguments tend to be made. First, it is pointed out that these excesses of colonialism were recognized as such, and widely criticized by contemporaries from within the ranks of the colonizers. ${ }^{22}$ Second, the claim is often made that we cannot hold the past to the moral standards of the present, and therefore we cannot use a twenty-first-century moral consciousness (whatever that may be) to judge what colonial regimes may have done. ${ }^{23}$ At the risk of some opportunism, then, this argument closes off the route for an ethically based critique of colonialism at both ends. Yes, these atrocities were awful. Europeans frequently pointed this out. Thus, the moral responsibility of colonizers for their actions is taken care of. At the same time, we live in a different and more equal world: the norms were different back then. Thus, the idea of assigning such moral responsibility is redundant in the first place.

3. Empire itself can hardly be seen as an aberration in history. Alien domination has been the rule, rather than the exception, in many societies. This claim appears in different modulations: it is made with a degree of rigour and caution in John Darwin's work, but more aggressively in the pronouncements of Biggar, Gilley, and Ferguson. The

19. Gilley, “The Case", p. 8.

20. Emmer, Zwart-wit denken voorbij, pp. 45-46.

2 I. Gilley, "The Case", p. 6.

22. Ferguson, Empire, pp. 318-324.

23. Emmer, Zwart-wit denken voorbij, pp. I8-19. 
consequences drawn from it, however, converge on one key point: the claim or implication that attempts to demonize modern empires based on an a priori rejection of foreign rule are necessarily anachronistic they ignore how "normal" imperial rule has actually been.

4. This clears the path for a wide-ranging attack on sovereign, postcolonial nation states as the fabrication of vested nationalist political interests. Decolonization is read as a gigantic political mistake, since the history of many postcolonial states has been marked by massive bloodletting, corruption, social cruelty, and poverty. ${ }^{24}$ Few serious scholars, of course, would deny the historical tragedies and crimes of decolonization; fewer still would make the claim - attributed to them by Biggar and Gilley - that colonialism is to blame for everything that has gone wrong in these societies, and that subsequent political leaderships bear no responsibility. The record of widespread misery and conflict is not in dispute. The implications of this, however, are twisted in a particular direction by Biggar, Ferguson, and most clearly by Gilley. The logical consequence, for them, of the crises of postcolonial development is very clear: these people simply cannot be trusted to govern themselves. This sets the stage for Gilley's most controversial conclusion: the recommendation for selective recolonization. "As in colonial times, foreign control by a liberal state with its own robust accountability mechanisms is the closest that a people with a weak state [i.e. the former colonized countries - PB and AS] can come to 'local ownership'." ${ }^{25}$ Their autonomy in shaping their future the great question posed by the twentieth-century anti-colonial traditions - is simply an irrelevance; what matters is whether they can be rescued by colonial traditions of "good governance".

5. All this implies that "we" should not be ashamed of "our" imperial past. Empire and its legacies should be celebrated, not subjected to the carping criticism of anti-colonial naysayers. Here, the attack swivels to confront its immediate enemy: an allegedly simple-minded, binary, authoritarian, politically correct academic consensus that claims empire was wholly detrimental for its subjects, and which is hostile to honest exchanges about the "real" benefits of empire. The title of an article by Lawrence James, "Empires Have Done Good and We Must Feel Free to Say So", neatly sums up the combination of a strident proclamation of imperial virtue with an escalation of rhetoric about the "denial" of rights of expression to those who believe in empire. ${ }^{26}$

24. Gilley, "The Case", pp. 5-7.

25. Ibid., p. 9.

26. Lawrence James, "Empires Have Done Good and We Must Feel Free to Say So", The Times, 5 December 2017. See also Kartar Lalvani, "Be Proud of the British Empire”, Daily Mail, 27 December 2017. 
These points more or less constitute the entire substance of the "case for colonialism". They also constitute its logical sequence. Firstly, there are claims that affirm the positive role of empire and underline its beneficial motives and outcomes. Secondly, anticipated criticisms are headed off by admitting - and simultaneously qualifying and rhetorically rendering diminutive - various discrete crimes and excesses committed under the aegis of colonial rule. The third step in this polemical framing is a specific kind of historical relativization that serves to naturalize empire: in "those" days, empire was accepted as a legitimate form of political rule, so we cannot sit in any sort of moral judgement upon it that is derived from our own moral experience. With this, the moral side of the case for colonialism is concluded, and we turn to unsentimental, hard-headed practical realism: what are the real problems and how can we solve them, now that these irrelevancies concerning the morality and legitimacy of colonialism have been disposed of?

This leads to the fourth step in the argument: the real disaster, plainly, has been the terrible record of many - most - postcolonial regimes. Decolonization was premature, since the formerly colonized societies have proven inherently incapable of looking after their own interests. The charge of blatant racism can be avoided by restating this argument through ever-so-practical recipes for "good governance", the model for which just happens to be the rule of former colonizers. In the fifth and concluding step, the argument turns full circle and resumes the battle against politically correct academic orthodoxies purveyed by left-wing, anti-colonial academia. We have here, in miniature, the structure of a culture war within academia, as perceived by the Right. ${ }^{27}$ Three elements are skilfully woven together in this discourse: a historical nostalgia linked to past supremacies; the inherent superiority of European values and accomplishments; and, finally, a "red scare" of sorts - the debilitating and false agenda of those naysayers who would deny the Western world the legitimacy of its pride in itself, its history, its values.

27. How strongly this form of historical revisionism is connected to current political developments, and how remarkably global the phenomenon is, is apparent from a controversial preelection interview by the Brazilian television show Roda Vida, in which the current president of Brazil Jair Bolsonaro argued that Africans, not Portuguese colonialism, are to blame for the slave trade to this country. The remark echoed Bolsonaro's general anti-black rhetoric and his embrace of the "positive legacy" of Portuguese colonialism. See the video at O Globo, I August 2018, available at: https://oglobo.globo.com/brasil/bolsonaro-na-tv-negar-divida-comescravidao-apagar-historia-diz-historiadora-22938430; last accessed 2 November 2018. Like its European and North American counterparts, the Brazilian far right can draw some of its inspiration for such claims from writers within or just outside the historical profession, for example the recent book by historical journalist Leandro Narlock, Guia politicamente incorreto da história do Brasil (São Paulo, 2009). 


\section{COSTS AND BENEFITS: CONSTRUCTING A POSITIVE BALANCE SHEET FOR COLONIALISM}

After teasing out the discrete elements of the "case for colonialism", we now turn to the underlying methodology: the "objective cost/benefit analysis" that allows Gilley and others to pose the question of colonialism's legacy in the form of a simple balance sheet in the first place. ${ }^{28}$ Colonialism, so runs the narrative, did many good things and some bad things. The good things - railways, education, human dignity in all its grandeur - were lasting treasures. The bad things - plunder, famine, the occasional genocide - were quickly reversed and left no lasting impression upon the societies within which they took place. The good things were uniquely and exclusively a European gift and could not have been arrived at without European rule. The bad things would probably have happened anyway and were tempered rather than triggered by European rule. ${ }^{29}$

At this level, where the achievements of empire are earnestly catalogued and its "dark side" rationalized away, the argument is, indeed, too banal to engage with. Gilley, as has been repeatedly pointed out, blithely disregards the copious evidence of vast famines, population displacements, violent partitions, and genocidal campaigns that accompanied imperial projects from their inception till their reversal. Nothing makes this clearer than his use of Belgian Congo as a primary candidate for recolonization by its former European overlords, casually ignoring the trail of bloodshed that the small European nation left behind in the vast African country that it had ruled. In this, Gilley is rather different from Niall Ferguson, the doyen of empirefriendly historians. Ferguson was strikingly frank about the violence and brutality of colonial endeavours in his book Empire: How Britain Made the Modern World, citing enslavement, transportation, and the ethnic cleansing of indigenous peoples as important aspects of colonial rule. ${ }^{30}$ As such, his work was more intellectually cogent than Gilley's, who concedes the existence of colonial atrocities in principle, but presents these as occasional and regrettable lapses, which are therefore not analytically admissible to any overall, structural understanding of colonialism.

28. Ferguson summarizes this overarching question as "simply whether the Empire was a good or bad thing", in order to challenge conventional wisdom "that, on balance, it was bad", Ferguson, Empire, p. xi.

29. With differences of emphasis, these views pervade the pro-empire monographs recently written by Niall Ferguson, Lawrence James, and Kartar Lalvani, as well as being the stance adopted by Gilley and Biggar. Contrary to claims of "silencing" by politically motivated and politically correct academics, such views enjoy wide circulation within the public sphere; several British daily newspapers (the Times, the Daily Telegraph, the Daily Mail, among others), for example, apparently consider it a binding duty to widely publicize defences of the British Empire.

30. Ferguson, Empire, p. 366. 
The uneven measuring of structural benefits against incidental crimes is compounded by a willingness to grant that certain specific forms of colonialism were uniquely criminal, but only in order to absolve one's own preferred form of colonialism of all sins. Thus, it is no coincidence that for Biggar, the ethics of empire are explicitly the ethics of the British Empire, with its supposed commitment to humanitarian values enshrined in the nineteenth-century commitment to the abolition of slavery and to liberal free trade that separated it from other contemporary empires. In Spain, in 2005, a fierce debate erupted in the pages of the journal Nuevo Mundo / Mundos Nuevos over the question of whether the Spanish conquest of the Americas should be called colonial at all, and whether it should be judged by the same negative standards as nineteenth-century British and French colonialism. ${ }^{31}$ In the controversies created by the French loi colonial of 2005 , those in favour of the law argued that colonial violence was indeed a regrettable aspect of the "first period" of colonialism, in which aims of conquest dominated the colonial agenda. However, this should not stand in the way of celebrating colonialism's "second period", characterized not by violence, but by the modernization of healthcare, the benefits of French education, and cultural progress. ${ }^{32}$ One of the rare merits of Gilley's full embrace of European colonialism as a whole is that he disavows a form of accounting in which the negatives are simply transferred to a different balance sheet that of the "bad" colonialism of other powers or a different age.

That, however, does not yet make the kind of cost-benefit calculation that Gilley advances scholarly rigorous. One of the interesting elements of contemporary empire revivalism is the manner in which a balanced account of costs and benefits is created, and the contrast between the kinds of quantities being measured on the credit and debit sides. The benefits of imperial rule are conveyed through a laundry list of large, structural changes: transport and communications networks, free trade, political integration, civil and criminal legal codes, the introduction of Western education and values, and so on. Each of these structural changes has been the subject of exhaustive scholarly investigation from multiple perspectives. Each of these, for a serious historian, opens up rather than resolves important historical questions and problems. In Gilley's thinking, however, the forms of modernity and capitalism ushered in by colonial rule are entirely unproblematic, a helping hand up the ladder of history to societies unable to "make it" on their own.

When it comes to the costs of colonialism, however, the unit of measurement is different - it consists of discrete and shocking events, not of

3I. Annick Lempérière, "La 'cuestión colonial'", Nuevo Mundo / Mundos Nuevos, online discussion dossier, available at: http://10.4000/nuevomundo.437; last accessed 2 November 2018. 32. Romain Bertrand, L'enjeu politique de la mémoire coloniale: le débat français (2005), available at https://hal-sciencespo.archives-ouvertes.fr/hal-010656 I 2; last accessed 2 November 2018), pp. $89-90$. 
processes and structures. Slavery was a very bad thing. So was the massacre of the Hereros. Some of the counter-insurgency measures used against anti-colonial fighters in Algeria and Kenya may have been rather brutal. The adventurers who enriched themselves through plunder during early phases of colonial rule were not playing cricket. The complaint against empire, through this sleight of hand, is turned into something rather trivial. Unlike the virtues of empire, which extend from the gift of individual liberty and human dignity to the gift of the modern bureaucracy, the drawbacks of the imperial project were temporary, reversible matters condensed into finite events. The drift of this purportedly "balanced" view is well exemplified in a comment by Biggar apparently acknowledging the morally mixed history of the British Empire: "Pride at the Royal Navy's century-long suppression of the Atlantic slave trade, for example, will not be entirely obscured by shame at the slaughter of innocents at Amritsar in 1919." 33 Details are thus abstracted from their contexts, and events are sundered from processes. Gilley takes this to absurd levels when he imagines a "controlled" recreation of colonial governance structures, picking out administrative recipes from colonial rule to fit to present African crises. The striking element here is not simply the call for a return to colonial rule, but the fact that it is advocated as a solution to intractable problems of hunger, violence, and governance. An imaginary ethical landscape is sketched out, with more than a touch of wistfulness, where certain countries conquer and rule other countries in order to solve their crises of state capacity, political security, and public service delivery. And this Panglossian picture is then projected backwards into the real colonial past: through another sleight of hand, colonialism itself is presented as though its primary purpose - or at least its primary historical function - was to solve the problems of "backward" societies. Here, Gilley and Biggar effectively rehearse the old theme of the white man's burden with a vengeance. Since the actual motives and interests animating the colonizing mission when it took place are not worthy of their consideration, the question of what concrete pressures might impel a resumption of colonial rule, today, is also irrelevant.

\section{THE MORALITY OF EMPIRE}

Let us turn to the arguments about the morality of empire posited during these controversies. It may be useful to begin from what might appear to be the two strongest points in the "case for colonialism" - the insistence on the historical relativization of both the legitimacy and the morality of empire. Without doubt, empires have been a long-lasting, dominant historical form of 
political rule and community - and not an aberration from the normal run of human affairs. Equally, without doubt, "our" contemporary moral standards - whatever those may be - are not the same as those who lived in past epochs, and the moral frameworks through which empire is glimpsed today are not those of a century ago. Taken together, these two points indicate the redundancy of any a priori, immanent critique of the imposition of foreign rule and the establishment of structures of colonial subjection. In Emmer's words, "we simply need to measure the past with a different measuring rod than the present". ${ }^{34}$ Most societies in human history have not been sovereign, so colonial rule was simply part of the order of things. The teleological character of this reasoning is amply demonstrated in a striking passage in Gilley's article, where he defends the principle of empire with reference to the civilizing impact of Roman rule upon Britain. Had Britain not been colonized by the Roman Empire, he states flatly, it would still be a "backwater of druid worshippers". ${ }^{35}$ Even making allowances for rhetorical overdrive, this suggests an extraordinarily flat and unilinear vision of historical movement and change, where certain variables can be neatly isolated from their contexts and tested for their specific historical efficiency.

Used in other ways, the relativization of contemporary ethical and political stances can be a useful analytic tool and can defamiliarize ways of being and social forms that appear natural and inscribed in the order of things to us. Gilley and others work in the opposite direction: they employ an argument from historically relative ethical standards to naturalize modern colonial domination, to make it seem an uncontroversial, rational historical trajectory for allegedly backward societies, thereby rendering colonial conquest, the extraction of resources, and political repression immune from any intrinsic or fundamental criticism. All modern sensitivities aside, the "real" historical lesson is "that empire is a form of international government that can work". ${ }^{6}$

An immediate analytical problem with this approach is that establishing a single moral "measuring rod" applied during the days of colonialism is as impossible as establishing one for today. Moreover, as several articles in our Virtual Special Issue demonstrate, the establishment of coercive structures under colonialism and the elaboration of modern discourses of freedom were mutually imbricated. There were - at least - two consequences to this. First, ideas of liberty and justice, which took root in a colonizing Europe, were frequently deployed to criticize and oppose colonialism itself, both within Europe and in the colonized world. Second, in a reverse movement, liberal ideologies of freedom were themselves moulded by the pressure of colonial expansion, and the development of ideas of liberty and autonomy

34. Emmer, Zwart-wit denken voorbij, 58 .

35. Gilley, "The case", 7.

36. Ferguson, Empire, 371. 
in the world of the colonizers was continually marked by strenuous attempts to rationalize the denial of these freedoms to colonized peoples. Finally, the process of imperial expansion was driven by the national interests of modern European nation states. In other words, nation formation (with its inbuilt ideologies of national self-determination) was part and parcel of an imperialist world order, and, conversely, the processes that generated imperial control also played their part in generating nationalist resistance to imperialism. In this light, Gilley's attempts to render anti-colonial nationalism as a kind of monstrous historical aberration, and anti-colonial positions as a backward projection of contemporary political correctness, are deeply contradictory. ${ }^{37}$

A related moral argument can be discerned in the peculiarly plaintive claim by Gilley, Biggar, and other empire apologists that "we" - presumably white Europeans and their descendants in North America and other white settler colonies - are constantly under pressure to "be ashamed" of empire and should be allowed to legitimately take pride in it instead. The shame/pride polarity configures the question of empire in a way that there can only be one winner. The criticism of empire, it is implied, is simply an act of ressentiment that seeks to see the West wallow in its own guilt. Quite implausibly, this argument goes on to say that "we" have, indeed, been stricken by this guilt and require a heroic effort to recover from it. Through a strange voluntarist twist, the question of how historians should study and evaluate empire is transformed, at a stroke, into the question "How should we feel about empire?" As James McDougall has argued, this question is entirely irrelevant to any sort of historical understanding, since it is not the job of historians to prescribe "how people should feel", but rather to present the evidence at hand and make the historical arguments that might fit it. ${ }^{38}$ But the absorption of historical judgement into the question of "how we should feel" does more than erect a straw man; it also pitches the argument about historical assessment upon a blatantly populist field. In a strange way, the drive within academia towards impact-driven metrics of worth corresponds here with the rising nationalist populism of the times, as a question that is entirely irrelevant to historical debate is turned into its arbiter.

The incoherence of the new defenders of empire's ethical position lies in the way it swerves between incompatible modes of moral reasoning. They furnish deontological foundations for their argument, making a case for empire as a morally justifiable first principle of political order. Imperial domination, in and of itself, is invoked as a moral project. In Gilley's words,

37. Most clearly in Gilley's remark that "those whose moral imaginations were not shrouded by anti-colonial ideology had the most productive encounter with modernity". Gilley, "The Case", p. 6.

38. James McDougall, “The History of Empire isn't About Pride - or Guilt”, The Guardian, 3 January 2018. 
the case for Western colonialism [...] involves reaffirming the primacy of human lives, universal values, and shared responsibilities - the civilising mission without scare quotes - that led to improvements in living conditions for most Third World peoples during most episodes of Western colonialism. ${ }^{39}$

At the same time, the defenders of empire argue along strictly utilitarian lines: empire was good because it produced beneficial consequences. ${ }^{4}{ }^{\circ}$ The connection between these two lines of argument is missing, because, philosophically, they are incompatible. If imperialism is to be justified in terms of a founding principle (the rights of conquest, or the duty to civilize inferior societies), then its concrete outcomes are, strictly speaking, irrelevant, in the same way as the case for democracy (and against despotism) can be made without comparing the concrete outcomes of democratic and despotic regimes. If, on the other hand, imperialism is to be judged on the basis of the outcomes it generated (which would imply an empiricist case-by-case evaluation), then logically its deontological foundations are beside the point. Gilley and Biggar cling on to the idea that empire is good both inherently and because of its consequences, but the two arguments, far from reinforcing each other as they might appear to do, cannot be brought together philosophically, let alone empirically. As a result, the case for colonialism proceeds in a thoroughly opportunistic manner. The essential benevolence of the colonizing mission is deployed as a defence against historical evidence of brutality and coercion, while the beneficial outcomes of "colonial good governance" are used as a knock-down argument against the charge that modern colonialism was an intrinsically unjust endeavour. Abstractions are used to rebut concrete evidence and cherry-picked, decontextualized details are used to rebut arguments from anti-colonial principles.

Finally, for all the contrived profundity of the empire apologists' moral claims about colonialism, their perspective is ultimately resolved into a very conventional form of social-Darwinism, modified by a crude utilitarianism and then applied to the history of modern empires as well as to the postimperial world. The underlying framework is methodologically nationalist: certain societies did well out of modernity and capitalism, others did badly. Those that did well, it is implied, used their superior military and technological prowess to do what any dominant country would do - they expanded their power globally. The strong benefited from and ruled over the weak, who suffered what they had to. But this is social-Darwinism with an implausibly happy ending for everyone, courtesy of the utilitarian framing of the argument. For, ultimately, it is claimed, colonial rule - in itself a rational form of the mastery of the more civilized and advanced over the backward - also justified itself by furnishing conquered societies with the gifts that they could use

39. Gilley, “The Case”, p. I.

40. Ibid., p. 3. 
to escape from their backwardness. The conditions for the greatest happiness for the greatest number, one might say, were laid by the survival of the fittest. Some postcolonial societies set out on the right path and did better than their unfortunate cousins, who were betrayed by the anti-colonial ideology that drove them to prematurely decolonize and thus condemn themselves to further backwardness. Here, Gilley furnishes the only logical conclusion that can proceed from such premises: to lift these benighted societies up, we need a return to the rational, benevolent, and eminently useful traditions of colonial mastery. Only the master's tools can rebuild the master's house.

\section{THE POLITICAL STAKES OF EMPIRE REVIVALISM}

Finally, there is the question of the political stakes of empire apologia. Here, it may be helpful to begin from what is clearly the governing element of their polemic: the mode in which it conceives of and identifies its opponent, the case against colonialism. Such arguments reduce anti-colonial critiques to their lowest common denominator: politically driven opposition to colonialism, both in principle and in practice. That this common strand exists is not disputed. What Gilley and others systematically misconstrue is where precisely this element sits within anti-colonial discourses and the role it plays. Consider, briefly, three of the major strands in the century-and-a-half old history of critiques of empire. There is, first, a long tradition of economic criticism, dominated by Marxist debates, but also comprising liberals like Hobson and later Schumpeter, and anti-colonial nationalists themselves. Here, we have long-running debates on the economic rationality of imperialism, its relations with an expanding global capitalism, forms of primitive accumulation based on the extraction of colonial resources, the changing weight of the pursuit of commodity markets and the pursuit of capital investments in the shaping of colonial policy, the deployment and control of cheap or coerced labour, and the significance of inter-imperialist economic rivalries. ${ }^{4 \mathrm{I}}$ There is a second tradition, particularly prominent in Francophone writing at the peak of decolonization (and in particular during the Algerian War), which absorbed but sought to transcend Marxist economic critiques. The writings of Fanon, Memmi, and Césaire stand out in this tradition. Here, colonialism was analysed principally as the encounter of antagonistic psychological disposition, the colonizer and the colonized appearing as stylized figures playing out a historical drama with precise determinants and coordinates. ${ }^{42}$ Finally, there

4I. For an excellent anthology of Marxist debates on imperialism before World War I, see Richard B. Day and Daniel Gaido (transls and eds), Discovering Imperialism: Social Democracy to World War I, Historical Materialism Book Series: Vol. 33, (Leiden and Boston, MA, 20I 2).

42. The argument was presented in its classical form in Frantz Fanon, Les damnés de la terre (Paris, 196I). 
is the influential tradition of postcolonial studies, which, conceived as a school, dates back to Said's Orientalism (1978). ${ }^{43}$ In this tradition, colonial power is understood chiefly as the operation of durable discourses that produced fixed, hypostasized points of reference for understanding conquered societies, and thereby generated equally fixed stereotypes about the "self" or the Western world. These are all distinct traditions that share a common rubric of anti-colonialism (there are other traditions, too, within this rubric), and each of them has generated key disagreements and debates.

Where does the claim that colonialism is bad sit within this cluster of anti-colonial arguments and vocabularies? It is indeed present at each stage of these arguments, but predominantly as an anchor, a guiding principle as well as a logical outcome of each scholarly investigation or polemical tract within these anti-colonial traditions. It does not seek to establish the "badness" of colonialism, but rather asks far more precise questions about its operation. These questions, however, are premised upon a negative assessment of colonial domination, which no doubt directs the line of enquiry as any framing hypothesis does. A brief glance at the contents of our Virtual Special Issue establishes what this amounts to. Each of the articles selected is clearly written from a perspective critical of colonialism. Yet, these perspectives differ from each other, throw different kinds of light upon colonial processes, and - centrally - do not set out to establish anything as banal as the claim that "colonialism was bad". A critical disposition towards colonialism is built into the objects of study chosen by these articles, and it is precisely this critical disposition that allows them to ask the dense empirical and conceptual questions that they do. An argument's premise is different from its substance. Gilley repeatedly conflates the two and is thereby able to present a many-sided, complex, internally fractious universe of anti-colonial thought as though it consists of the single-minded repetition of a single, simplistic negative judgement about colonialism. In this way, he reduces diverse traditions of both political and scholarly critique to the level at which the new apologists of empire themselves operate. For, in Gilley's own arguments about colonialism, substance and premise are identical. There is no place for analytical questions about the structure of colonial power, about the purposes it served, or, indeed, anything besides the question of whether it was good or bad. The axiom is the conclusion; the conclusion is the axiom.

Why is it necessary for scholars defending colonialism to work at such a reductive level of argument? Here, it might be useful to take stock of the way in which Gilley and like-minded scholars frame the political significance of their endeavours. They encourage an imperial nostalgia that rests, by definition, upon the celebration of past forms of Western global supremacy, and resuscitates, also per definition, the most traditionalist beliefs of yesteryear. 
At the same time, they present themselves as crusading rebels against a stifling orthodoxy of political correctness, as radical questioners of anticolonial doxa that nobody else dares question. This is a significant exercise in self-positioning. After all, it is not in everyone's power to be both the Sheriff of Nottingham and, at the same time, Robin Hood.

It is in the outlines of this self-positioning that we can trace the contours of an ongoing culture war, in which history writing, and the humanities more generally, has a significant place. The university sector in which all of the new defenders of empire work is part of a social world in which open prejudice and discrimination against differently constituted minorities - along the lines of race, gender, and sexuality - is far less legitimate than it once was. Consonant with this, once "normal" expressions of patriotism, with the flag signalling a glorious empire, are considered jingoistic. These ideological developments are historically rather new, rooted in cultural changes that have worked their way through Western societies since the I960s. Broadly liberal notions of equality and diversity have entered not only academic curricula, but also managerial strategies within universities on both sides of the Atlantic, and themes of racial discrimination, sexual harassment, homophobia, and transphobia make headlines in various parts of the world, particularly in the historical centres of industrial capitalism. In a later defence of his position on colonialism, Gilley himself provides a glimpse of how this shift appears to someone with his political stance:

My home institution did not acquit itself well. This is not surprising. Whole departments - especially our new 'School of Gender, Race And Nations' - are already branded with a certain ideological stamp. The question for them is not whether but how to attack colonialism and 'decolonise' everything they lay their hands on. ${ }^{44}$

To adapt Marx's old phrase, in certain influential areas of public opinion in the West - and to a more uneven extent elsewhere - certain notions of formal equality in language, law, and policy, and the corresponding delegitimation of open forms of social discrimination, have "acquired the fixity of a popular prejudice". The limits of such transformation, however, have also become starkly visible of late, as these egalitarian advances have been confronted by a powerful cultural backlash. It is within the terms of this backlash that polemics like Gilley's find their strength. The advance of the far right across Europe, the anti-migrant jingoism enshrined in British national policy by Brexit, the grotesquerie of Trumpism, constitute the second, and much larger, current flowing through the centres of Western liberal democracy.

44. Bruce Gilley, "How the Hate Mob Tried to Silence Me", Standpoint Magazine, December 2017/January 20I8, available at: http://www.standpointmag.co.uk/print/7027; last accessed 5 October 2018. 
They represent a massive, sustained backlash against the fragile social gains made since the I960s by social, sexual, and ethnic minorities. Currently, countries across the world - those where this shift seemed firmly ensconced, as well as those where it was always weaker - seem to be experiencing a potentially radical reversal of several of these gains. Powerful ideological currents today pit the "rootless cosmopolitanism" of social progressivism against the grass-roots "authenticity" of whiteness, national pride, antiimmigration sentiment, and male supremacy.

There are, of course, many mediating factors that intervene between these seismic political shifts and the specific ideological themes at work within history writing about empire. But sometimes very direct connections are discernible. In Britain, a 20I4 YouGov opinion poll indicated that fifty-nine per cent of those interviewed felt "more proud than ashamed" of the British Empire, against a mere nineteen per cent with the opposite feeling. ${ }^{45}$ Subsequently, some of the Conservative government's desperate attempts to bolster Commonwealth trade in the parlous climate of an impending Brexit were christened "Empire 2.0" by government figures, apparently in the belief that this would prove popular in the former colonies. In France, significantly at the opposite end of the political spectrum, Jean-Luc Melenchon took it upon himself to state that the French Empire had been better than the British Empire, being more of a "family affair" because of the rights the French conferred upon their colonial subjects. Across the world, public pressures have moved many governments steadily in the direction of a pronounced right-wing nationalism in recent years. One manifestation of this is a hunger for the symbols and rhetoric of imperial greatness. The glee with which the popular media in particular have greeted the controversies created by Gilley and Biggar in the anglophone world, and by like-minded scholars in France or the Netherlands, is more a vector of this hunger than of the scientific merit of their respective contributions.

\section{MISREPRESENTING THE FIELD: LABOUR HISTORY AS A TEST CASE}

The previous sections concentrated on analysing the deep logical flaws in the arguments put forward by the new apologists of empire. Many of those reveal the revisionists to be enthusiastic practitioners of the unscholarly practices that they most aggressively decry. In the name of creating a measured balance sheet including the positive and negative contributions of colonialism to social development, they present their highly subjective selections of

45. "The British Empire is 'Something to Be Proud Of'”, 26 July 2014, available at: https:// yougov.co.uk/topics/lifestyle/articles-reports/201 4/07/26/britain-proud-its-empire; last accessed 3 December 2018. 
incommensurables. How many miles of railroad built by the colonial powers or children educated in missionary schools equate to the worsening of the effects of the El Niño famines by imperial policies, the indignities produced through the application of scientific racism, or the systematic employment of torture in the Algerian War? Starting from a claim of restoring dispassionate empiricism against the ideologically charged anti-colonial narratives, the new defenders of empire reduce a multi-levelled debate on the varied and contradictory strands of the colonial past to a flat playing field on which they can let good and bad factors engage in an intractable exercise of moral juggling. In order to liberate colonial history from politicization due to its alleged left-wing bias, it employs the entire rhetorical arsenal of the new right. ${ }^{46}$ One could argue that despite the internal inconsistencies of the revisionists' arguments and the pseudo-scientific methods they employ to score cheap points, their attacks could have a positive result on the development of the field by exposing certain biases in existing research. By collating a representative selection of densely argued historical engagements with one facet of colonial rule - its effects upon the world of work - it is possible to demonstrate that even this would be rather too generous. Moving away from polemics, the following sections will turn to the place of colonial labour history within the development of Global Labour History to show that the significant advances made in research were only gained as a result of the rejection of the Eurocentrism that long pervaded the historical profession. This also shows that a deepening of those advances is premised on the continued rejection of the kind of colonial nostalgia that the revisionists promote.

Historiography is one of the main terrains on which the case for colonialism is constructed. Revisionist historians conjure up an image in which decolonization and the influence of left-wing ideologies within academia in the I 970 s completely changed the focus of entire academic fields, marginalizing the narrative of Western exceptionalism, which they are now keen to restore to its former position of pride. This view matches popular prejudices about a "left-wing bias" of the humanities. However, it is completely at odds with more standard descriptions of the development of Western academic debates on this theme. While social movements in the I960s and I 970 certainly promoted critical reflections on the imperial past on the heels of decolonization, it took many years before this had any sustained impact on the historical profession. And even then, it long remained confined to the margins of the field. As Remco Raben notes in a recent survey, "the weak integration of metropolitan and imperial histories seems to be characteristic of most post-imperial

46. This includes the strategic use of irony, to allow one to present arguments without ever feeling the need of claiming responsibility for them. How to argue, for example, against Pieter Emmer's "politically incorrect thought game", in which he suggests, tongue in cheek, that "without the internal and external slave-trade, [African] famines would have claimed many more victims"? Emmer, Zwart-wit denken voorbij, p. 76. 
societies". ${ }^{47}$ Nor did the slow advance of anti-colonial voices, further stimulated by the growing assertiveness of postcolonial migrant communities, ever come close to silencing old-style imperial narratives. In France, the law of 2005 stipulating positive education about the French colonial past only put in judicial terms what numerous academics and right-wing activist groups had been arguing openly since Algerian independence. ${ }^{4}$ Despite his artistry in posing as the perennial underdog, Pieter Emmer remained a highly influential professor of colonial history in the Netherlands throughout the supposedly stifling years of all-pervasive political correctness.

The evolution of the IRSH neatly illustrates how slow and incomplete the shift towards a non-Eurocentric approach to history has been, even in such a "progressive" area of research as labour history. Labour history has some claim to stand - with other streams of scholarship - at the source of the "progressive" structures of reasoning that evoke such hostility from Gilley and other empire apologists. This is not principally, in the first instance at least, because of labour history's own engagement with colonialism, which has been extensive, but also belated and uneven. Rather, it has to do with the fact that history from below is one of the major post-1960s trends in the writing of history that sought quite directly to locate itself on the side of the exploited and dominated against hegemonic social structures and agents of domination. The same case can be made for feminist scholarship, sexuality studies, critical race studies, and a variety of research sub-fields that are positioned - by themselves as well as by their detractors - on the progressive side of the cultural divide.

Since the IRSH's remit, for much of its existence, has been labour history, this will be the focus of the historiographical examination that follows. Taking a closer look at the trajectory of labour history generates significant insights. First, the surprisingly late global turn of labour research occurred only in the I990s. Despite the radical aims of many practitioners of labour history who published in the IRSH from its foundation in 1956 onwards, it was not till fairly late in its existence that the journal's scope extended beyond Europe and North America. Second, as indicated earlier, tracing the evolution of the journal once it started to move beyond European case studies illustrates the largely irrelevant nature of the "was colonialism good or bad?" debate, which seems to have captivated corners of public discussion in tandem with the latest controversies. The articles published in this Virtual Special Issue range from the inherent paradoxes in the idea of free labour when applied to the colonial world, to the persistence of coercive modes of labour extraction; from the attempts by colonial regimes to deploy customary forms of labour regulation, to the innovation of new forms of remuneration and labour

47. Remco Raben, 'A New Dutch Imperial History? Perambulations in a Prospective Field', BMGN / Low Countries Historical Review I 28:1 (2013): pp. 5-30, 7.

48. Bertrand, L'enjeu politique, pp. 79-83. 
control; from the uneven spread of global capitalism into colonial settings, to the relationship between labour movements and anti-colonial struggle. A diversity of experiences is relayed through these studies of power and resistance in colonial contexts. Contrary to the canard spread by Gilley and others, the effect of this focus on domination and resistance is not the reduction of colonialism to a monolithic, undifferentiated force, but the very opposite.

\section{COLONIAL LABOUR HISTORY AND THE IRSH'S TRAJECTORY}

Despite the great upheavals in colonized countries, in which organized labour played a major part, colonial labour relations and labour movements did not figure strongly in the pages of the IRSH until the I990s. In fact, hardly any country outside a narrow range of European nations ever did, as the breakdown of articles from the I 970 presented in Table I illustrates. Out of 143 research articles, I 22 dealt with Western Europe. More than half of the total output (seventy-four articles) focused on the UK. So strong was this bias that in 1978 the Editorial Board could publish a research note under the title "Strikes and the Press in the North-East, I 8 I 5-44", assuming that the readers would understand that this generic geographical direction indicated the north-east of England, Newcastle upon Tyne to be precise. ${ }^{49}$ In the entire decade that is supposed to have ushered in the wholesale collapse into post-colonial guilt among social scientists, only four research articles focused on countries outside Europe and the US. Of those, one dealt with the impact of the Russian Revolution on the (predominantly white) trade union movement in Australia, and one with the reverberations of the Paris Commune of I 87 I in the 1927 workers' uprising in Guangzhou. The remaining two contributions had a direct bearing on the theme of colonialism. Apart from the article on China, the extensive Special Issue on the Paris Commune published in 1972 contained an overview by Marcelo Segall of its impact in Latin America. One of the more notable aspects of this article is that it draws attention to the temporal proximity between the Paris uprising in $187 \mathrm{I}$ and the insurrection in the French Caribbean colony Martinique a year earlier. Still, the author felt compelled to introduce this section of his article with the remark that "rapprocher ces deux événements peut paraitre relativement insolite à un Européen, de même sans doute qu'à la majorité des Latino-américains".50 Dick Kooiman's 1978 article on "Jobbers and

49. J.V. Corrigan, "Strikes and the Press in the North-East, I 8 I 5-44: A Note", International Review of Social History, 23:3 (1978), pp. 376-38r.

50. Marcelo Segall, "En Amérique Latine. Développement du mouvement ouvrier et proscription", International Review of Social History, 17:I-2 (1972), pp. 325-369, 33 I. The article was translated from a Spanish original. 
Table I. Geographical Focus of Original Research Articles* in the IRSH, 1970-1979.

\begin{tabular}{|c|c|c|c|c|c|c|c|c|c|c|c|}
\hline & 1970 & 1971 & 1972 & 1973 & 1974 & 1975 & 1976 & 1977 & 1978 & 1979 & Total \\
\hline Western Europe (total) & 9 & 6 & 24 & 13 & 14 & 13 & 11 & 12 & 12 & 8 & 122 \\
\hline Eastern Europe (total) & 1 & & 4 & & & 1 & & & & & 6 \\
\hline US & & & 1 & & 1 & & 1 & & 1 & 1 & 5 \\
\hline Non-European or US & & & 2 & & & & & 1 & 1 & 1 & 5 \\
\hline Non-country based & 1 & & & & 1 & 1 & 1 & & 1 & & 5 \\
\hline Total number of research articles & 11 & 6 & 31 & 13 & 16 & 15 & 13 & 13 & 15 & 10 & 143 \\
\hline
\end{tabular}

* Excluding the sections Survey, Suggestions, and Debates, and Review Essay. The extraordinarily large number of articles in 1972 was mainly due to the publication of a 623-page Special Issue on the Paris Commune and its international impact. 
the Emergence of Trade Unions in Bombay City" therefore stands out as the only contribution to the journal in the I 970 s that delved into colonial labour relations without any reservations or apologies. ${ }^{5 \mathrm{I}}$

The narrow geographical focus of the journal partly reflected its origins. Founded as the academic journal of the International Institute of Social History (IISH) in Amsterdam, it initially functioned primarily as an outlet for publications centred on the source collections of the IISH's archive, which, at that time, were mostly oriented towards Western Europe and Russia. A secondary aim, to function as a general publication for labouroriented social history, gradually evolved into the journal's main objective. Although there was no explicit policy to exclude non-European subjects, the all-pervasive Eurocentric bias within the humanities in general was unthinkingly mirrored in the IRSH's editorial policy as well. ${ }^{52}$ However, there were also reasons specific to labour history as a sub-field within social history, which allowed this bias to continue longer than in other areas. ${ }^{53}$

Traditional labour history focused primarily on the organizational history of labour institutions such as trade unions and left-wing political parties, viewed through the lens of Western European patterns of class formation. The central actor in this history was the male, white, industrial wage worker, who was seen as the backbone of working-class social struggles and politics. Cases where other types of labour relations prevailed - as they did in most colonial countries - were studied mainly for their deviation from this supposed norm. A good example of this tendency in the early years of the IRSH is H.R.C. Wright's article on opium cultivators in Benares in the late eighteenth century, one of the few pre-1990 articles dealing with India. While prefiguring the later interest of the journal in the relationship between forced and free labour in a colonial context, the article still assumed that the logical direction of development ran from the former to the latter. The problem that the author set out to explain

5. Dick Kooiman, "Jobbers and the Emergence of Trade Unions in Bombay City", International Review of Social History, 22:3 (1977), pp. 313-328.

52. That the journal did not, on principle, exclude contributions with a wider geographical scope, is apparent from the publication in an early issue of A.N. Bose, "Evolution of Civil Society and Caste System in India”, International Review of Social History, 3:I (1958), pp. 97-I 2 I.

53. The difference can easily be checked by comparing Table I with the Tables of Contents of the two most influential social history journals of the I970s, Past and Present and Annales. Both resemble the $I R S H$, in that apparently without trepidation they could fill consecutive issues with articles on not much more than rural England and rural France, speckled perhaps with a few Flemish or Swiss towns. Nevertheless, when examined over the entire decade, Past and Present already published quite a number of notable contributions on Africa, Latin America, and Asia, while Annales, with its strong global outlook, arguably already from early on was in a different league when it came to attention to the non-European world. On the latter, see Peter Burke, "The Annales in Global Context", International Review of Social History, 35:3 (1990), pp. $42 \mathrm{I}-432$. 
was why the desire for reform in the direction of freedom under the law "had been sacrificed for a time to the material interests of the Company". ${ }^{4}$ The publication of E.P. Thompson's The Making of the English Working Class, and the new social history that followed it, challenged the exclusive focus on the male industrial worker, but not the Anglo-centrism of traditional labour history. ${ }^{55}$

The shift towards Global Labour History, and thereby towards an opening up of the pages of the journal to non-Western historical experiences and a larger number of writers not based in Europe or the US, came rather abruptly in I990. Both internal and external factors precipitated this change. Externally, it is crucial to point out the cumulative effect of advances in non-Western labour history, made by historians of the non-European world, area specialists and anthropologists. In the I970s and I980s, important debates on forced labour, working-class formation and working-class movements took place among scholars in Latin America, Africa and Southern Asia, and also penetrated Western academia, although initially they did not manage to shake the core assumptions within traditional labour history. ${ }^{56}$ On the basis of these advances, scholars such as Dipesh Chakrabarty and Samir Amin raised powerful challenges "from the outside" to the notion that the Western European path of industrial working-class formation was universally valid. ${ }^{57}$ Internally, in the I980s, Marcel van der Linden became editor of the IRSH and a newly formed research department came under the leadership of Jan Lucassen. Though very different in their background and scholarly inclinations, they found each other in their ambition to make labour history encompass the entire globe. ${ }^{58} \mathrm{~A}$ two-page mission statement in the first issue of 1990 by the Editorial Committee, entitled "Free and Unfree Labour", announced the new direction of the journal. It started from the acknowledgement that "implicitly the International Review of Social History has always concentrated on the free wage labourers, their living and working conditions, struggles and

54. H.R.C. Wright, "The Emancipation of the Opium Cultivators in Benares", International Review of Social History, 4:3 (1959), pp. 446-460, 460.

55. Despite its own focus on England, however, Thompson's work did influence the emergence of new labour histories outside of Europe, which later would help stimulate the emergence of Global Labour History. See the Special theme on “The Global E.P. Thompson”, especially Gabriel Winant, Andrew Gordon, Sven Beckert, and Rudi Batzell, "Introduction: The Global E.P. Thompson”, International Review of Social History, 6r: I (2016), pp. I-9.

56. Regional overviews of the pre-1990s advances in scholarship can be found in Jan Lucassen (ed.), Global Labour History. A State of the Art (Bern, 2006).

57. Samir Amin, Eurocentrism (London, I989), pp. I I9-I 22; Dipesh Chakrabarty, Rethinking Working-Class History. Bengal I 890-1940 (Princeton, NJ, I989), pp. 222-223.

58. Marcel van der Linden and Jan Lucassen, Prolegomena for a Global Labour History (Amsterdam, 1999); Jan Lucassen, "Workers: New Developments in Labor History since the I980s", in Ulbe Bosma and Karin Hofmeester (eds), The Lifework of a Labor Historian: Essays in Honor of Marcel van der Linden (Leiden and Boston, MA, 2018), pp. 22-46. 
organizations". ${ }^{59}$ It continued with the need to problematize this focus on one type of labour for different parts of the world, including what was then usually called the Third World. This automatically raised the issue of colonialism and its aftermath:

As far as the colonial period is concerned, one can ask oneself under which circumstances the authorities attempted to promote wage labour, but also why they so often preferred unfree labour. For the post-colonial period, it is important to ask to what extent the further penetration of the market economy has overcome or, indeed, strengthened the colonial and local obstacles to free labour and to investigate the role of the state in this process. ${ }^{60}$

Of course, the effects of this new direction were not immediately visible in the journal's pages. However, in the course of the I990s, the number of contributions on colonial labour history, as well as non-Western labour history more broadly, did start to increase. The first Special Issue predominantly devoted to colonial labour relations appeared in 1996, under the editorship of Shahid Amin and Marcel van der Linden. Their introduction made clear that studying so-called peripheral labour not only functioned to establish divergences from a Western model, but actually helped to undermine essential presumptions of that model itself. Thus, studying colonial labour relations "may also shed new light on the history of the labouring classes in the so-called core countries". ${ }^{61}$ As Table 2 shows, the shift in direction really changed the geographical scope of the journal over time. While still far from evenly balanced (especially given the different weight in terms of population size), more than one third of the research articles published in the $2000 \mathrm{~s}$ focused on areas outside Europe and the US. Many of those concerned colonial and recently decolonized countries, with a special emphasis on India where labour history had emerged as an important topic immediately in the wake of decolonization. ${ }^{62}$ Far from sacrificing scholarly rigour to political correctness, as the revisionists claim, a long-overdue diversification of inquiry and authorship finally took place in the course of the ragos. Those who argue that this critical agenda has gone too far do not propose to move beyond a research agenda that has run its course; they vociferously advocate a rollback of a scholarly advance that has just begun.

59. The Editorial Committee, "Free and Unfree Labour", International Review of Social History, 35:I (1990), p. I.

6o. Ibid., p. 2.

6r. Shahid Amin and Marcel van der Linden, "Introduction”, International Review of Social History, 4IS (I996), pp. I-8, 4 .

62. Sabyasachi Bhattacharya, "Introduction", International Review of Social History, 5 IS (2006), pp. $7^{-19}, \mathrm{I} 7$. 
Table 2. Geographical focus of original research articles* in the IRSH, 2000-2009.

\begin{tabular}{|c|c|c|c|c|c|c|c|c|c|c|c|}
\hline & 2000 & 2001 & 2002 & 2003 & 2004 & 2005 & 2006 & 2007 & 2008 & 2009 & Total \\
\hline Western Europe (total) & 9 & 8 & 6 & 4 & 2 & 9 & 7 & 14 & 5 & 4 & 68 \\
\hline Eastern Europe (total) & & 1 & & 2 & 2 & & & 2 & & 1 & 8 \\
\hline US & 1 & 3 & 3 & 5 & & 1 & 1 & 1 & 1 & 1 & 17 \\
\hline Non-European or US & 4 & 4 & 5 & 6 & 9 & 3 & 9 & 6 & 7 & 8 & 61 \\
\hline Cross-country or Multi-country & 1 & 2 & 1 & 1 & 3 & 4 & & 1 & 6 & 2 & 15 \\
\hline Total & 15 & 18 & 15 & 18 & 16 & 17 & 17 & 24 & 19 & 16 & 175 \\
\hline
\end{tabular}

* Excluding the sections Survey, Suggestions and Debates, and Review Essay. 


\section{FIRST RESULTS: FORCE, TRADITION, RESISTANCE, AND LEGACIES}

The twelve articles selected from the IRSH's back catalogue for this Virtual Special Issue were chosen to showcase how much was gained by the reorientation of the I990s. Every selection is partial by definition. Nevertheless, these articles bring to the fore core observations about what can be said to constitute labour history's case against colonialism. None of the articles do so by idealizing pre-colonial conditions or postcolonial states, or in the kind of denunciatory tone stereotyped by writers such as Gilley. Careful and measured analysis suffices to make the case against colonialism.

Unsurprisingly, the main aspect of colonial labour relations that all the contributions draw attention to is the persistence of coercion. Gyan Prakash sets out the significance of this question in the most programmatic way, in his 1996 article "Colonialism, Capitalism and the Discourse of Freedom”. In it, he challenges the heuristic value of defining capitalism by the application of free wage labour, by introducing the contradictory impact of capital in a colonial context:

Whether it was slavery and indenture on the "New World" plantations, or bonded labour on the Indian subcontinent, they were constituted as the Other of free labour; what marked them was an economy of restrictions - restraints on the mobility of labourers, impediments on their ability to choose and change employers, controls over their culture, etc. With labour power turned into an exchangeable commodity, capitalism constituted other social forms of labour as the opposite of free exchange. ${ }^{63}$

The importance of this contribution lies in the paradox that it expresses. On the one hand, imagining coerced labour practices as traditional and counterpoising them to the liberalism of Western labour relations, at least from the nineteenth century onwards, provided a crucial justification for colonial rule. On the other hand, colonial rule itself relied on the continuous adaptation and reproduction of coerced labour. Prakash examines this paradox concretely by studying the transformation of the Indian kamias, a group of agricultural labourers bound through long-term ties to the landlords, from slavery to debt bondage. From this, he concludes that

the rule of commodities and markets took shape in and profited from structures ranging from peasant production to plantation slavery, though it represented them as its opposite. In this sense, the history of unfreedom is the history of capital in disguise. [...] For it was the colonial discourse and transformations generated by British rule that reconstituted a range of dependent ties in the inverse image of free labour. ${ }^{64}$

63. Gyan Prakash, "Colonialism, Capitalism and the Discourse of Freedom", International Review of Social History, 4 IS (1996), pp. 9-25, I0.

64. Ibid., p. 22. 
It is especially important to underline the centrality of questioning latecolonial commitments to the promotion of free labour, given the ease with which revisionist scholars leave out the long legacies of the application of force in colonial labour relations from their consideration of the institutional impact of imperial control. One of the prime contributions that labour history can make to the study of colonial policies is to concretize the question of the meaning of freedom in the colonial context, by examining its practical application in the organization of work. The willingness of colonial powers to adopt forced labour has often been explained as a sign of the weakness of the (early) colonial states in the face of local practices. In another contribution on India, Ravi Ahuja challenges this interpretation. Following the emergence of colonial labour regulation in the eighteenth century, he shows that the efficiency of regulative measures and the readiness of colonial administrators to intervene in pre-existing social relations developed in tandem. The colonial state, however, did not use such increased powers to rein in practices of coercion, but rather to "experiment in the application of well-established techniques of domination to a new social context". ${ }^{65}$ That the contradiction between colonial states' claims of furthering free labour institutions while actually relying on a redefinition, regulation, or reorganization of coerced labour institutions was not confined to the earlier phases of colonialism is shown by Alexander Keese's article on French and British labour policies during the end-phase of colonial rule in West Central and South Central Africa. At this time, the 1957 sharpening of the ILO convention on forced labour already put great pressure on the colonial powers to abolish compulsory labour services. Despite their professed adherence to ILO standards, which have often been taken as a step towards decolonization and a contribution to beneficial post-independence labour practices, Keese shows that deeply ingrained prejudices that made up the "colonial mindset" precluded French and British administrators to seriously strive for the full abolition of coercion. Instead, they reintroduced forced labour practices "through the backdoor", by giving autonomy to local chiefs and using them as suppliers of coerced labour, or by relying on vagrancy laws to force African subjects into labour services through judicial sanction. ${ }^{66}$

The notion of colonial labour reforms as a contribution to the modernization of inherently static pre-colonial societies - crucial both to colonial ideology itself, and to the recent reinterpretation of colonialism as beneficial in the long run - principally relies on the designation of all kinds of forced labour practices and other inequalities as "traditional". In his I995 study of the strict

65. Ravi Ahuja, "The Origins of Colonial Labour Policy in Late Eighteenth-Century Madras", International Review of Social History, 44:2 (1999), pp. I 59-195, I9I.

66. Alexander Keese, "Slow Abolition within the Colonial Mind: British and French Debates about "Vagrancy", "African Laziness", and Forced Labour in West Central and South Central Africa, I945-1965”, International Review of Social History, 59:3 (2014), pp. 377-407. 
forms of labour control and discipline imposed on the street sweepers of Delhi through jobbers, overseers, and contractors, Vijay Prashad challenges the notion that the power of such intermediaries over manual labourers was simply a legacy of India's pre-colonial past. Instead, he shows how "far from rationalizing Delhi's sanitation system, the colonial regime fostered a system which relied upon extra-economic coercion which today gives credence to the lie that India is tradition enshrined". Thus, he is able to prove that in the case of the street sweepers, "'tradition' is itself a child of colonial modernity, whose dynamic is neither progressive nor reactionary, but stagnant". ${ }^{67}$

Perhaps even more than in the area of labour control, the question to what extent colonialism acted as a modernizing force looms large in discussions of the family and gender relations. In her 1997 article on domesticity and dependence in Bengal, Samita Sen traces the way in which employers' attitudes, middle-class ideologies of propriety, and the policies of the colonial state conspired “to divest women's activities of economic value and promoted female dependence on male earnings" ${ }^{68}$ Comparing household arrangements in Bengal to the well-known narrative of the emergence of the ideal of the family wage in the course of British industrialization, Sen argues that Bengali women remained economically active much longer, though not in the same economic spheres as men. However, colonial accounting tended to obscure the extent of women's labour by only counting work performed outside of the household. ${ }^{69}$ From the I920s onwards, the idea of the male provider became increasingly important in Bengali industry, a tendency that was supported by the colonial and the postcolonial state alike.

Demonstrating the necessity to take into account the varieties in policies and attitudes developed by different colonial states, in 2016, Elise van Nederveen Meerkerk detected a more or less opposite trend in Dutch approaches towards women's work in Indonesia. When, in the first decades of the twentieth century, incipient forms of social security in the Netherlands became strongly linked to the principle of the male breadwinner, Dutch authorities and intellectuals actively sought new justifications for the need to maintain female and child labour in Indonesia. This divergent development, actively promoted by the Dutch colonial state, relied on an increasingly explicit "grammar of difference". Thus, Van Nederveen Meerkerk draws attention to the importance of racism to the colonial state's interventions in labour relations. ${ }^{70}$

67. Vijay Prashad, "Marks of Capital: Colonialism and the Sweepers of Delhi", International Review of Social History, 40:I (I995), pp. I-30, 3.

68. Samita Sen, "Gendered Exclusion: Domesticity and Dependence in Bengal", International Review of Social History, $42 \mathrm{~S}$ (1997), pp. 65-86, 66.

69. Ibid., p. 7 I.

70. Elise van Nederveen Meerkerk, "Grammar of Difference? The Dutch Colonial State, Labour Policies, and Social Norms on Work and Gender, c.1800-1940", International Review of Social History, 6IS (2016), pp. I37-I64. 
The difficulty of separating pre-colonial tradition from adaptation and new creation in the functioning of colonial societies is one of the reasons why the kind of cost and benefit analysis proposed by the revisionists produces such superficial and skewed results. A further reason for this is that it is particularly difficult to integrate into a cold analysis the amount of destruction wrought by colonialism on particular peoples and societies. Genocide, ecocide, and mass enslavement accompanied colonization from inception. Stefan Halikowski Smith's article brings this out most clearly, in a contribution that deals with the fifteenth-century conquest by the Spanish and Portuguese of the mid-Atlantic islands. "The European arrival in the Canary Islands", he holds, "heralded the full-scale population collapse of its light-skinned native Guanches peoples". Defeated by a combination of military onslaught and the plague, "on Christmas Day I 492 the last Guanches surrendered in Tenerife. Remaining insurgents were hunted down from the hills, their traditional dress was outlawed and they were sold as slaves and put to work on the new sugar plantations". ${ }^{71}$

Finally, against such horrors some of the more "positive" results of colonialism completely ran counter to the intentions of the colonizers and occurred in the teeth of their fierce resistance. The contributions by Ibrahim Abdullah and by Ian Phimister and Alfred Tembo both illustrate how an organized labour movement arose in close connection to anti-colonial agitation. As Abdullah points out, strike waves and movements of the urban poor pushed the colonial administrators of Freetown in Sierra Leone to tinker "with the minutest detail of workers' lives as well as issues that questioned the meaning of colonialism itself". ${ }^{22}$ Despite intimidation and violence, labour movements emerged that were capable of pressurizing both the colonial and the postcolonial state.

One of the unique contributions of Global Labour History is its insistence on the need to study labour relations from a long-term comparative perspective. Introducing such perspectives can help to overturn long-standing prejudices on non-Western labour relations that partly informed, and partly were reinforced, by colonial labour policies. One such prejudice is the idea that "traditional" non-Western labourers were particularly immobile, while the introduction of capitalist labour markets through the impositions of the colonial state helped to "free" labourers from their place-boundedness as well as other types of bonds. In "On the Move: Circulating Labor in Pre-Colonial, Colonial, and Post-Colonial India”, Ian Kerr turns this around by insisting

7I. Stefan Halikowski Smith, “The Mid-Atlantic Islands: A Theatre of Early Modern Ecocide?”, International Review of Social History, 55 S (2010), pp. 5I-77.

72. Ibrahim Abdullah, “'Liberty or Death': Working Class Agitation and the Labour Question in Colonial Freetown, 1938-1939", International Review of Social History, 40:2 (1995), pp. 195221, 195; Ian Phimister and Alfred Tembo, "A Zambian Town in Colonial Zimbabwe: The 1964 'Wangi Kolia' Strike”, International Review of Social History, 60S (201 5), pp. 4I-62. 
on the long-lasting traditions of travelling transport workers, the Banjaras, as well as the migratory patterns among construction workers. Despite its attempts to "marginalize, compartmentalize, and criminalize itinerant groups" to make them less mobile, and therefore make them easier to control and exploit, the British state did not manage to break such traditions. ${ }^{73}$

The long potential afterlife of colonial labour practices and their effect on persistent inequalities is apparent from Julia Martínez's discussion of the remuneration of Aboriginal workers in Australia. An older history of settler colonialism at the cost of the indigenous populations led to a situation in which, as late as the I950s, "Aboriginal workers in the Northern Territory were expected to work for little more than food, clothing, and tobacco." 74 However, Martínez also proves that one of the main components of this already meagre payment in kind, clothes, often consisted of uniforms that labourers were not allowed to keep outside their jobs. She thereby affirms the need to scrutinize even the most mundane claims of authorities about the labour conditions of their subject populations, a necessity that only increases when dealing with a colonial state and workforce. It is no coincidence that especially in the metropoles, such careful dissection of the information provided by the colonial states was first undertaken by their adversaries. The final contribution to this Virtual Special Issue engages with the work of the French sociologist Pierre Bourdieu, who undertook such a dissection in the context of the mounting struggle for Algerian independence. By comparing Bourdieu's conclusions with that of the major anti-colonial thinker Frantz Fanon and by showing how his Algerian inquiries influenced Bourdieu's re-interpretation of traditional Marxist concepts, Andrea Rapini recovers the long tradition of furthering social science through a critical engagement with the experience of colonialism. ${ }^{75}$

\section{CONCLUSIONS}

Based on the articles selected for this Virtual Special Issue, as well as the evolution of the IRSH's involvement in the field of colonial labour history, the last two sections show that though labour history was slow to begin the decolonization of its perspective, once it did, the results were impressive. When emancipated from its Eurocentric baggage, labour history can add

73. Ian J. Kerr, "On the Move: Circulating Labor in Pre-Colonial, Colonial, and Post-Colonial India", International Review of Social History, 5 IS (2006), pp. 85-109, I00.

74. Julia Martínez, "When Wages Were Clothes: Dressing Down Aboriginal Workers in Australia's Northern Territory”, International Review of Social History, 52:2 (2007), pp. $27 \mathrm{I}-286$.

75. Andrea Rapini, "Can Peasants Make a Revolution? Colonialism, Labour, and Power Relations in Pierre Bourdieu's Algerian Inquiries”, International Review of Social History, 61:3 (2016), pp. 389-42I. 
significantly to an understanding of colonial policy and societies. This should come as no surprise, since the forced extraction of goods and the organization of the labour necessary to obtain them were among the colonial powers' primary aims. Labour history is particularly well-situated to study the tensions between colonial states' modernization discourse and developmental claims, and their persistence in the application of large-scale coercion in social organization. It can situate colonialism within longer trajectories in the evolution of labour relations, which include pre-colonial and postcolonial society. It can help to clarify why, in certain phases of their existence, colonial states were more capable of penetrating deep into their subject societies than in others, and why precolonial traditions were sometimes resilient in the face of the colonial onslaught, and sometimes proved highly adaptable for colonialism's purposes. Finally, by natural inclination, it highlights the role of labour movements as prominent actors in the process of decolonization.

However, a rejection of the tendency to reinstate the Eurocentric notions behind the colonial project is not only necessary because of what a broader, and truly internationally executed labour history could continue to bring to the study of colonialism. It is also imperative for the continued development of labour history itself. Here, it might be useful to revisit some hypotheses formulated by Shahid Amin and Marcel van der Linden in the early i990s. First, drawing on work by Gyan Prakash, they argued that colonial labour relations could provide essential tools for understanding the general importance of intermediary forms of labour between free, independent, and unfree labour, including their occurrence in Western societies. Second, they pointed out that the experience of what was then called the Third World proved that "'Modern' capitalism may involve the reconstitution of slavery [...], as well as the reconstitution of older forms of industry." Third, they pointed out that the intermediary forms of wage labour might best be regarded "as articulations of a worldwide segmentation of the labour force". ${ }^{76}$ One precondition for testing these hypotheses is the careful and unprejudiced research of colonial labour, of which twelve excellent examples are presented in this Virtual Special Issue. A second precondition would be to use the results of such research to actively seek ways in which colonial labour relations, directly or indirectly, shaped the evolution of labour relations in the metropolitan countries. Suggestions in this direction can be found in the selected articles. However, overall this road remains far less explored. It forms one significant way in which the field of colonial labour history can continue to be at the forefront of deepening Global Labour History's research agenda.

It is precisely because of the need to advance labour history's research agenda that this article has taken stock of the revisionist historians' attempt 
to rehabilitate colonialism. One of the reasons why the controversy surrounding Gilley's article in the Third World Quarterly has proven so toxic is that Gilley and his supporters managed to shroud their attack on an entire field of scientific enquiry in the language of the defence of pluralism and free speech against politically correct censorship by a left-wing academic establishment. Against such facile claims, which clearly parallel the language of the new right in the public sphere, this introduction has purported to show that the reason to reject the revisionist case rather resides in the scholarly unsound and, at times, even pseudo-scientific nature of the arguments that its proponents wield. In terms of methodology, the form of cost-benefit accounting proposed to judge the merits of colonialism relies on a series of contradictory premises. In its approach to basic research findings, it rests on either straight denial of, or the cultivation of ignorance about, the work of several generations of historians and social scientists of all possible hues, in favour of worn-out clichés that were once promoted by the colonial powers themselves. As a historiographical intervention, its basis is a gross misrepresentation of the nature and content of the schools of study against which it positions itself. The only way that a thriving field can defend itself against such a multi-levelled attack on scholarship is by showing, in practice, the vitality of its approaches, the diversity of voices and agendas that it promotes, and the many ways in which it contributes to our understanding of the present and the roads that led towards it. The essays selected here do precisely this.

\section{TRANSLATED ABSTRACTS \\ FRENCH - GERMAN - SPANISH}

Pepijn Brandon et Aditya Sarkar. L'bistoire du travail et les accusations contre le colonialisme.

La controverse autour de l'article de Bruce Gilley, "The Case for Colonialism" a attiré l'attention mondiale vers un courant de revendications et de vues révisionnistes sur l'histoire du colonialisme, né ces dernières années dans le monde universitaire et les médias. Des auteurs tels que Niger Biggar au R.U., Niall Ferguson aux E.U. et Piet Emmer aux Pays-Bas ont tous publié des revendications semblablement révisionnistes sur le colonialisme, soutenant que la culpabilité postcoloniale et le "politiquement correct" aveuglent la majorité de leurs collègues quant au côté positif du projet colonial. Leur argument fait écho à des tendances sociétales plus larges, transformant les défenseurs révisionnistes de l'empire en héros d'un droit nationaliste revigoré dans le monde universitaire et au-delà de ce dernier. L'influence publique que ces approches du colonialisme ont atteinte contraint les historiens à dénoncer les graves erreurs méthodologiques, la mauvaise lecture de faits historiques et les fausses représentations de connaissances antérieures qui caractérisent les écrits de cette tendance révisionniste émergente. C'est pour cette raison que le Comité 
éditorial de l'International Review of Social History (IRSH) a décidé de consacrer son tout premier Virtual Special Issue aux accusations de l'histoire du travail contre le colonialisme. Cet article, qui est également une introduction au Virtual Special Issue, examine minutieusement les implications logiques des revendications de Gilley et des érudits du même courant de pensées, en contextualisant et réfutant leurs arguments. Après avoir évalué la longue absence de la relation de travail colonial dans le champ d'intérêt des historiens du travail, et des pages de l'IRSH elle-même, cet article montre qu'une critique du colonialisme est au centre du tournant mondial de l'histoire du travail dans les années 1990. En utilisant un choix d'articles sur l'histoire du travail colonial provenant des propres archives de l'IRSH, l'article construit non seulement "l'histoire du travail contre le colonialisme", mais montre aussi pourquoi il conviendrait d'approfondir et d'élargir les aperçus critiques de l'histoire du travail concernant la nature du colonialisme.

\section{Traduction: Christine Plard}

Pepijn Brandon und Aditya Sarkar. Arbeitsgeschichte und die Argumente gegen den Kolonialismus.

Die Kontroverse um Bruce Gilleys Aufsatz »The Case for Colonialism« (»Argumente zugunsten des Kolonialismus «) hat weltweit Aufmerksamkeit auf die stete Folge revisionistischer Aussagen und Sichtweisen auf die Kolonialgeschichte gezogen, die in den vergangenen Jahren sowohl im akademischen Bereich als auch in den Medien $\mathrm{zu}$ verzeichnen gewesen ist. Autoren wie Nigel Biggar aus Großbritannien, Niall Ferguson aus den USA und Piet Emmer aus den Niederlanden sind sämtlich mit vergleichbar revisionistischen Aussagen über den Kolonialismus an die Öffentlichkeit gegangen und haben dahingehend argumentiert, postkoloniale Schuldgefühle und political correctness würden der Mehrheit ihrer Kollegen die Sicht auf die positiven Aspekte des kolonialen Projekts verstellen. Diese These stößt aufgrund allgemeinerer gesellschaftlicher Entwicklungen auf Anklang, sodass die revisionistischen Fürsprecher imperialer Politik zu den Helden einer innerhalb wie außerhalb des akademischen Bereichs neu erstarkenden nationalistischen Rechten werden. Der öffentliche Einfluss, den diese Herangehensweisen an den Kolonialismus mittlerweile entfalten, verlangt von Historikern, dass sie die gravierenden methodologischen Fehler, die Fehldeutung historischer Tatsachen und die verzerrte Darstellung früherer Forschungsarbeiten aufdecken, durch die sich die Schriften dieser erstarkenden revisionistischen Tendenz auszeichnen. Aus diesem Grund hat sich der Redaktionsausschuss der International Review of Social History (IRSH) entschlossen, erstmalig eine virtuelle Sonderausgabe herauszugegeben, die arbeitshistorischen Argumenten gegen den Kolonialismus gewidmet ist. Der Beitrag, der zugleich die Einleitung zur virtuellen Sonderausgabe ist, erkundet die logischen Implikationen der von Gilley und vergleichbar gesinnten Forschern getätigten Behauptungen und arbeitet zugleich auf eine Kontextualisierung sowie auf eine Widerlegung ihrer Argumente hin. Nach einer Auseinandersetzung mit dem langjährigen arbeitshistorischen Desinteresse an kolonialen Arbeitsverhältnissen, wie es sich auch in der Themenwahl der Zeitschrift IRSH niedergeschlagen hat, arbeitet der Beitrag die zentrale Rolle heraus, die die Kritik am Kolonialismus beim global turn der 
Arbeitsgeschichte in den I990er Jahren gespielt hat. Unter Rückgriff auf ausgewählte Untersuchungen zur kolonialen Arbeitsgeschichte aus dem IRSH-Archiv formuliert der Beitrag nicht nur »Argumente gegen den Kolonialismus «, sondern zeigt darüber hinaus auch die Gründe auf, aus denen es die kritischen Einsichten der Arbeitsgeschichte in das Wesen des Kolonialismus zu vertiefen und auszuweiten gilt.

Übersetzung: Max Henninger

Pepijn Brandon y Aditya Sarkar. La historia del trabajo y el proceso contra el colonialismo.

La controversia suscitada por el artículo de Bruce Gilley "The Case for Colonialism" ha generado una atención generalizada hacia una corriente de planteamientos revisionistas y de visiones de la historia del colonialismo que emergió en el ámbito académico y en los medios de comunicación a lo largo de los últimos años. Autores como Nigel Biggar en el Reino Unido, Niall Ferguson en los Estados Unidos y Piet Emmer en los Países Bajos han publicado tetos revisionistas sobre la cuestión del colonialismo desde perspectivas muy semejantes sosteniendo que la culpa postcolonial y la corrección política han hecho que la mayoría de sus colegas no vean el lado positivo del proyecto colonial. Sus argumentos enlazan con tendencias sociales muchos más amplias transformando a estos revisionistas defensores del imperio en heroes de una derecha nacionalista revigorizada dentro y fuera del mundo académico. La influencia pública alcanzada por estas perspectivas sobre el colonialismo obliga a quienes nos dedicamos a la historia a poner al descubierto los graves defectos metodológicos, la interpretación errónea de hechos históricos y la tergiversación de propuestas previas que caracterizan los escritos de esta corriente revisionista emergente. Precisamente por esta razón el Comité Editorial de la International Review of Social History (IRSH) ha decidido dedicar su primer número especial virtual a la cuestión del proceso de la historia del trabajo contra el conlonialismo. En este artículo, que sirve de introducción a este número virtual especial, hace un repaso de las implicaciones lógicas de las propuestas realizadas por Gilley y otros académicos que secundan esta corriente, elaborando tanto una contetualización de estas propuestas como una refutación de los argumentos que presentan. Después de realizar un análisis de la larga ausencia de la cuestión de las relaciones laborales coloniales como ámbito de interés de los historiadores/as del trabajo, incluso en las propias páginas de la $I R S H$, en este artículo se demuestra la centralidad de una crítica al colonialismo en el giro global que se tuvo lugar en la historia del trabajo en la década de i990. Haciendo uso de una selección de textos sobre la historia del trabajo colonial existentes en el archivo de la IRSH no sólo se construye un proceso de la historia del trabajo contra el colonialismo sino que también demuestra porqué debe de seguir profundizándose y extenderse la perspectiva crítica de la historia del trabajo sobre la naturaleza del colonialismo.

Traducción: Vicent Sanz Rozalén 